\section{Psychotic symptoms in social anxiety disorder with bipolar- like progression}

\section{Sintomas psicóticos na fobia social com evolução bipolar}

\section{Dear Editor,}

Previously, our research group discovered that there is a subgroup of social anxiety (SA) patients who improve while taking antidepressants and present a clear hypomanic phase. Without the antidepressant, the symptoms of SA return ${ }^{1}$. SA and bipolar disorder II (BD-II) patients have a similar number of previous depressive episodes, alcohol abuse, suicide attempts, and family history of mood disorder ${ }^{1}$.

There is a lack of studies on the association between SA and mania. We will discuss $\mathrm{BD}$ associated with psychotic symptoms in SA by describing a case seen in an anxiety outpatient clinic ${ }^{2}$.

\section{Case report}

A 45-year-old female was referred due to habitual anxiety caused by routine social interaction. The patient often felt judged and incapable of labor-intensive activities. Symptoms stabilized after eight months of venlafaxine $(75 \mathrm{mg} /$ day $)$ and clonazepam (1.2 mg/day). Eight weeks after stabilization she presented affective lability, irritability, feelings of being deliberately excluded by colleagues, that her parents had caused her marital separation and, during the exam, feelings that the psychiatrist was able to read her mind and know her feelings. She was brought to the clinic after an argument with her boss, in which she accused him of plotting to physically attack her, interpreting that her boss had hit a door to attack her when he was actually just watching a soccer match. At the consultation, she presented with exalted mood, agitation and affective lability with a predominant expression of intense grief and suffering, despite stating that she had never felt better. The patient was taken to the hospital and maintained on a regimen of venlafaxine (75 mg/day) and clonazepam ( $2 \mathrm{mg} /$ day $)$ in order to prevent loss of therapeutic benefits. Risperidone (4 $\mathrm{mg}$ /day) was initiated instead of a mood stabilizer during the crisis due to diagnostic inaccuracy before the longitudinal observation. The state that led to her hospitalization was diagnosed as a manic mixed episode. After three weeks, the patient had a satisfactory remission and was able to resume a normal level of functioning.

\section{Discussion}

The case presented in this letter highlights the relationship between SA and BD. We observed a patient with SA who, after symptom improvement with antidepressants, had a clear manic phase. Other studies have also reported clinical similarities between $\mathrm{SA}$ and BD-II ${ }^{3}$, as well as a link between BD-I and SA: 12.5\% of patients with BD-I also have $\mathrm{SA}^{4}$. Himmelhoch ${ }^{3}$ studied the treatment outcome of 32 social anxiety disorder patients and found that 18 had remission ( $>50 \%$ ) of their SA symptoms. Moreover, 14 out of those 18 became hypomanic, according to mania scales and expert clinical diagnosis. We found that this patient with SA that featured a bipolar-like progression experienced manic symptoms, and particularly a mixed episode. We identified additional occurrences of psychotic symptoms related to SA worries, such as concern about being accepted by others.

Once patients with SA begin to feel preoccupied with the minds of others, they show a predisposition toward psychotic symptoms ${ }^{5}$. Another predisposing factor in some patients with SA is the observation of bipolar-like progression, which indicates the possibility not only of hypomanic episodes but also of manic episodes with psychotic symptoms.

\section{André Barciela Veras, Júlia Santana do Nascimento, Antonio E. Nardi \\ Panic \& Respiration Laboratory (PRL), Institute of Psychiatry, Federal University of Rio de Janeiro, INCT Translational Medicine (CNPq), Brazil Santa Casa Sociedade Beneficente de Campo Grande} (SBCG) - MS 
Disclosures

\begin{tabular}{|c|c|c|c|c|c|c|c|}
\hline $\begin{array}{l}\text { Writing group } \\
\text { member }\end{array}$ & $\begin{array}{c}\text { Employ } \\
\text { ment }\end{array}$ & $\begin{array}{l}\text { Research } \\
\text { grant }^{1}\end{array}$ & $\begin{array}{c}\text { Other } \\
\text { research } \\
\text { grant or } \\
\text { medical } \\
\text { continuous } \\
\text { education }\end{array}$ & $\begin{array}{l}\text { Speaker's } \\
\text { honoraria }\end{array}$ & $\begin{array}{l}\text { Ownership } \\
\text { interest }\end{array}$ & $\begin{array}{l}\text { Consultant/ } \\
\text { Advisory } \\
\text { board }\end{array}$ & Other $^{3}$ \\
\hline André B. Veras & $\begin{array}{l}\text { PRL- } \\
\text { SBCG }\end{array}$ & - & - & - & - & - & - \\
\hline $\begin{array}{ll}\text { Júlia S. do } & \text { do } \\
\text { Nascimento }\end{array}$ & SBCG & - & - & - & - & - & - \\
\hline $\begin{array}{ll}\text { Antonio } & \text { E. } \\
\text { Nardi }\end{array}$ & $\begin{array}{l}\text { PRL- } \\
\text { UFRJ }\end{array}$ & $\begin{array}{l}\text { CNPq, } \\
\text { INCT }\end{array}$ & - & - & - & CNPq & - \\
\hline
\end{tabular}

* Modest

** Significant

*** Significant: Amounts given to the author's institution or to a colleague for research in which the author has participation, not directly to the author.

PRL: Panic \& Respiration Laboratory; SBCG: Santa Casa Sociedade Beneficente de Campo Grande; UFRJ:

Universidade Federal do Rio de Janeiro; CNPq: Conselho Nacional de Pesquisa e Desenvolvimento; INCT: Instituto

Nacional de Ciência e Tecnologia - Medicina Translacional

\section{References}

1. Valença AM, Nardi AE, Nascimento I, Lopes FL, Freire RC, Mezzasalma MA, Veras $\mathrm{AB}$, Versiani M. Do social anxiety disorder patients belong to a bipolar spectrum subgroup? J Affect Disord. 2005;86(1):11-8.

2. Hallak JE, Crippa JA, Quevedo J, Roesler R, Schröder N, Nardi AE, Kapczinski F. National Science and Technology Institute for Translational Medicine (INCTTM): advancing the field of translational medicine and mental health. Rev Bras Psiquiatr. 2010;32(1):83-90.

3. Himmelhoch JM. Social anxiety, hypomania and the bipolar spectrum: data, theory and clinical issues. J Affect Disord. 1998;50:203-13.

4. Pini S, Maser JD, Dell'Osso L, Abelli M, Muti M, Gesi C, Cassano GB. Social anxiety disorder comorbidity in patients with bipolar disorder: a clinical replication. J Anxiety Disord. 2006;20(8):1148-57.

5. Veras AB, do-Nascimento JS, Rodrigues RL, Guimarães ACA, Nardi AE. Psychotic symptoms in social anxiety disorder patients: report of three cases. Int Arch Med. 2011,4:12-16. 